\title{
UK legislation, European legislation and table of cases
}

\section{UK LEGISLATION}

Companies Act 198535

Companies Act 2006 27, 34, 36, 48

Transnational Information and

Consultation of Employees

Regulations 1999, S.1. 1999, No

$3323 \quad 48$

\section{EUROPEAN LEGISLATION}

Council Directive 97/74/EC of 15

December 1997 extending, to the

United Kingdom of Great Britain and Northern Ireland $\mathbf{4 8}$

Council Regulation EC No

$2157 / 2001$ of 8 October 2001 on the Statute for a European company (SE) $\mathbf{4 0}$
Council Directive 2001/86/EC of 8 October 2001 supplementing the Statute for a European company with regard to the involvement of employees $\mathbf{4 0}$

\section{TABLE OF CASES}

\section{UK cases}

$H L$ Bolton (Engineering) Co Ltdv TJ Graham \& Sons Ltd [1957] 1 QB $159 \quad 27$

Smith and Fawcett Ltd [1942] Ch 30435

Percival v Wright 1902 Ch 421

35

Hutton v West Cork Railway Co.

(1883) $223 \mathrm{ChD} 65436$ 
Christine A. Mallin, Eve Mitleton-Kelly, Ahmed Al-Hawamdeh, and Iris Hse-Yu Chiu - 9781849808002 Downloaded from PubFactory at 04/26/2023 02:36:41PM 